Rocznik Andragogiczny

\title{
Wojciech Solarz, Andrzej Sowa (red.), Zofia Solarzowa - życie spełnione. Pisma społeczne i literackie, Stowarzyszenie „Promni”, Warszawa 2015, ss. 428
}

W ostatnim okresie na rynku wydawniczym ukazał się wartościowy poznawczo tom tekstów źródłowych, stanowiący wybór utworów literackich i publicystycznych Zofii Solarzowej - ps. Chrzestna (1902-1988). Jego wydanie zawdzięczamy Stowarzyszeniu „Promni” powołanemu do życia dla wspierania Ludowego Zespołu Artystycznego Szkoły Głównej Gospodarstwa Wiejskiego o tej samej nazwie, którego Solarzowa była współzałożycielką i w latach 1973-1974 pierwszą prowadzącą (Sowa 2010).

Na blisko 400 stronicach pomieszczono w tomie różnorodne w formie teksty jej autorstwa. Część pierwsza zawiera dłuższe formy prozatorskie (m.in. Skalnych ludzi wg wydania drugiego - poprawionego i uzupełnionego, LSW 1967, czy - szczególnie cenne, bo nieopublikowane nigdy wcześniej Skalne drogi, o których istnieniu wiedzieliśmy od lat 70. XX wieku, kiedy to sama Solarzowa wspomniała o nich w Moim pamiętniku), wiersze (21 utworów poetyckich - zarówno tych publikowanych w przedwojennym piśmie "Wici”, jak i tych powojennych pozostających dotychczas głównie w rękopisach - w zestawieniu syna Wojciecha Solarza), wybór inscenizacyjnie opracowanych pieśni (wg jej pomnikowego dla międzywojennej kultury ludowej Teatru z pieśni wydanego przez Instytut Teatrów Ludowych w 1933 roku). Warto też dostrzec zamieszczenie w części pierwszej - bezpośrednio po tekście, do którego się odnosi - Stownika „Skalnych ludzi” w opracowaniu Agaty Bentkowskiej, pozwalającego uściślić informacje biograficzne o bohaterach występujących w tym utworze.

W części drugiej - szkoda, że zdecydowanie krótszej - odnajdziemy z kolei 11 artykułów i szkiców o charakterze społeczno-publicystycznym. Obok kilku znanych już wcześniej tekstów poświęconych np. Jędrzejowi Cierniakowi (Kolega Jędrzej z 1982 roku) czy mężowi Ignacemu Solarzowi (Przyjaciel ludzi i świata z 1983 roku) możemy zapoznać się także z treścią 
siedmiu artykułów, które do tej pory pozostawały jedynie w rękopisach. W interesujący sposób dopełniają one naszą wiedzę o poglądach ich autorki na wiele kwestii społecznych, politycznych i artystycznych. Szczególnie interesujące, gdyż przybliżają niezbyt często podnoszone dotychczas fakty z życia pierwszego Solarzowego uniwersytetu ludowego, informacje znajdzie czytelnik w szkicu poświęconemu Adamowi Polewce (Adam Polewka $w$ Szycach). Warto też w tej części nieco więcej uwagi poświęcić na przestudiowanie uwag Solarzowej dotyczących miejsca ruchu ludowego i mieszkańców wsi w powojennej Polsce (Głos w sprawie chtopskiej do rzq̨dzq̨cych i rzq̨dzonych Obywateli Rzeczypospolitej - Ludowej Polskiej) - są one bowiem bardzo pouczające i dziś. (Szkoda jedynie, iż redaktorzy opracowujący materiał nie pokusili się o próbę choćby przybliżonego datowania zamieszczonych w tej części rękopisów).

Cały prezentowany tu tom uzupełniają rozważania wprowadzające, na które składają się Słowo od wydawcy Jarosława Kalinowskiego, szkic Jedność sztuki i życia Rocha Sulimy, krótkie wspomnienie Leszka Leśniaka (Oni sq tacy i już!) oraz Kalendarium - wybór faktów z życia Zofii Solarzowej autorstwa Doroty Truszczak (w którym niestety odnaleziono kilka nieścisłości np. w datowaniu pierwszego wydania Mojego pamiętnika czy omyłka (?) diametralnie zmieniająca kontekst wejścia przez „Chrzestną” w skład Narodowej Rady Kultury).

Zofia Solarzowa była niewątpliwie postacią dalece wykraczającą poza typowy obraz ludowej działaczki społecznej, nauczycielki uniwersytetów ludowych czy animatorki kultury na wsi. Jak wiemy, także dzisiaj przez wiele środowisk i autorów - związanych np. z ruchem ludowym, z Towarzystwem Uniwersytetów Ludowych i innymi kręgami UL-owskimi w naszym kraju czy $\mathrm{z}$ rodzimym teatrem amatorskim i jego historią, uznawana jest za postać wybitną, której spuściznę i przesłanie należy starannie pielęgnować i rozwijać. Wystarczy wziąć do ręki choćby inspirującą do dziś książkę Bronisława Gołębiowskiego sprzed dwóch dekad pt. Cywilizacja słońca. O aktualności i perspektywach idei polskich uniwersytetów ludowych Zofii i Ignacego Solarzów (1994) czy zajrzeć do ostatniego szkicu Lucjana Turosa poświęconego Solarzowej (2016, s. 191-206), by odnaleźć ten sposób narracji prezentującej postać i dorobek bohaterki oraz dostrzec nie tylko wielki szacunek dla jej niewątpliwych osiągnięć, ale i wielką estymę, jaką nieodmiennie od lat obdarzają ją inni. Jak np. pisze ten ostatni: „Solarzowa całym swoim życiem, pracą, działalnością społeczną dała dowód, że sprawy wychowania estetycznego, społecznego i moralnego młodzieży chłopskiej są jej szczególnie bliskie 
i że potrafi mądrze, twórczo, umiejętnie przygotować ją do wartościowego udziału w życiu społecznym i kulturze" (Turos 206, s. 206).

Mniej liczni autorzy (i działacze ludowi) - również doceniając jej dorobek - zdają się widzieć niektóre z aspektów działalności Solarzowej w odmienny sposób. Według ich opinii, o ile w zasadzie nie budzi żadnych wątpliwości przedwojenny i wojenny okres jej działalności, to jednak przynajmniej niektóre wybory dokonywane przez nią po wojnie mogą nasuwać pewne wątpliwości czy budzić (zwłaszcza współcześnie) pewne kontrowersje. Wydaje się, że trafnie zilustrowała ten sposób podejścia do spuścizny Zofii Solarzowej przed kilku laty Agnieszka Majewska-Kafarowska w monotematycznym numerze „Edukacji Dorosłych”, poświęconym pionierskim postaciom andragogiki, oceniając szesnastoletni okres pracy Solarzowej na Podhalu: „Było też w Białym Dunajcu kilka sytuacji [...], które gmatwają nieco ocenę jej działalności, postawy. Jak mniemam, to one także spowodowały, iż dość niechętnie podejmowano się po jej śmierci oceny jej działalności, dorobku, gdyż niejako burzyły pewien porządek. Chodzi tu mianowicie o udział lub organizowanie uroczystości dla Urzędu Bezpieczeństwa, Milicji Obywatelskiej czy też uroczystości ku czci Lenina, do którego gorliwie przekonywała górali. Zresztą jak i do socjalizmu, który uważała wtedy za ustrój mogący ulepszyć świat" (Majewska-Kafarowska 2010, s. 136). Odrębną kwestią, podnoszoną także m.in. przez Rocha Sulimę w rozważaniach wprowadzających do książki (s. 16-17) pozostaje przy tym fakt, jak sama Chrzestna rozumiała swoje zaangażowanie $\mathrm{w}$ budowę nowego ustroju. Interesujące oświetlenie także i tej kwestii znajdziemy u samej Solarzowej w jednym z po raz pierwszy publikowanych w omawianym tomie szkiców: „Myślę, że socjalizm - to nazwa kierunku i busoli orientująca przywódców naszego społeczeństwa, bo oni odpowiadają za kierunek i treści życia narodu. My zaś odpowiadamy za nazwę każdego, najintymniejszego uczucia ludzkiego. Osobiście na przykład nie życzyłabym sobie, aby mi kazano wierzyć i mówić, że kocham swoje dzieci socjalistycznie, że wzruszam się piosenką góralską socjalistycznie i nawet że dla socjalizmu żyję i pracuję. Natomiast z najgłębszą radością, z miłością i zaufaniem, z dumą nawet - mogę i chcę widzieć w socjalistycznym kierownictwie mojego kraju gospodarską troskę o najbujniejszy rozkwit sił twórczych w każdym człowieku i w całym narodzie, o godność człowieczeństwa obywateli, o ich rzetelność i kulturę wykwitającą z pracy, z pracy dla wszystkich" (s. 222).

Większość z osób zainteresowanych postacią i dorobkiem Zofii Solarzowej nie miała do tej pory większych szans „osobistego spotkania” z jej tekstami zawartymi w książce, albowiem albo pozostawały one w ręko- 
pisach, albo też opublikowano je przed laty w (niemal) niedostępnych już dzisiaj dla szerszego odbiorcy miejscach. Bardziej znany pozostawał jedynie Mój pamiętnik (mający dotychczas trzy wydania: 1973, 1985, 2013). W dużej części wiedza o Chrzestnej czerpana bywała zatem z „drugiej ręki”, tak więc czytelnicy - siłą rzeczy - musieli polegać na opiniach i ocenach innych autorów. Obecnie - dzięki wydanym przez Stowarzyszenie „Promni” Pismom społecznym i literackim - uzyskaliśmy szansę zarówno na osobiste zmierzenie się z dorobkiem pisarskim Zofii Solarzowej, jak i możliwość rozpoznania jej sposobu myślenia czy samodzielnego dokonania oceny postawy oraz wrażliwości artystycznej i społeczno-politycznej. Dajmy więc szansę źródłom. Gorąco zachęcam do podjęcia tego wysiłku.

Tomasz Maliszewski

\section{Bibliografia}

Gołębiowski B. (1994), Cywilizacja słońca. O aktualności i perspektywach idei polskich uniwersytetów ludowych Zofii i Ignacego Solarzów, Towarzystwo Uniwersytetów Ludowych, Fundacja Polskich Uniwersytetów Ludowych, Warszawa.

Majewska-Kafarowska A. (2010), Zofia Solarzowa, ta, która czuła niezawodne sity twórczego przekazywania ludziom ich własnego życia, [w:] A. Stopińska-Pająk (red.), Pionierki i pionierzy andragogiki, „Edukacja Dorosłych” nr 2(63), s. 125-138 .

Solarzowa Z. (1973), Mój pamiętnik, Ludowa Spółdzielnia Wydawnicza, Warszawa. Sowa A. (2010), Po prostu „Promni”, Muzeum Historii Polskiego Ruchu Ludowego, Stowarzyszenie „Promni”, Warszawa.

Turos L. (2016), Wychowanie estetyczne w ujęciu teoretycznym i w doświadczeniu Zofii Solarzowej, [w:] T. Maliszewski, M. Rosalska (red.), Uniwersytety ludowe - pomiędzy starymi a nowymi wyzwaniami, Wydawnictwo „Adam Marszałek”, Toruń 2016, s. 191-206. 